\title{
A Review of Balcony Impacts on the Indoor Environmental Quality of Dwellings
}

\author{
Catarina Ribeiro ${ }^{1, *}$, Nuno M. M. Ramos ${ }^{1}\left(\mathbb{D}\right.$ and Inês Flores-Colen ${ }^{2}$ (D) \\ 1 CONSTRUCT-LFC, Faculdade de Engenharia (FEUP), Universidade do Porto, Rua Dr. Roberto Frias s/n, \\ 4200-465 Porto, Portugal; nmmr@fe.up.pt \\ 2 CERIS, DECivil, Instituto Superior Técnico (IST), Universidade de Lisboa, Av. Rovisco Pais, \\ 1049-001 Lisboa, Portugal; ines.flores.colen@tecnico.ulisboa.pt \\ * Correspondence: catarina.ribeiro@fe.up.pt
}

Received: 19 June 2020; Accepted: 1 August 2020; Published: 11 August 2020

\begin{abstract}
Balconies are an ancient architectural archetype that are being increasingly considered in multi-family buildings of high-density cities. This paper aims to provide a comprehensive review of the impacts of balcony types on the indoor environmental quality (IEQ) and energy consumption of dwellings. Of the reviewed studies, $69 \%$ were published during the last decade, making it evident that awareness of the positive impact of balcony spaces is continuously increasing. The literature review allowed us to identify three balcony spaces according to their morphology and their boundary system: open balcony (OB), glazed balcony (GB), and eliminate balcony (EB). It was concluded that these balcony types produce relevant impacts in four factors that contribute to the indoor environmental quality: thermal comfort, indoor air quality, visual comfort, and acoustic comfort. Practical design recommendations and constraints were provided according to distinct climatic conditions and building technologies. This review also explored the assessment methodologies used for the optimization of the balconies on the design process. The literature highlighted the lack of a comprehensive study about the impact of balconies in mild and Mediterranean climates, as well as the knowledge limitations concerning the balance between the impacts on IEQ factors.
\end{abstract}

Keywords: balconies; glazed balconies; residential buildings; comfort; indoor environmental quality; building passive strategies; energy efficiency

\section{Introduction}

Developing compact and high-density cities is becoming a strategy to promote sustainable development, accommodating population growth and mitigating human impacts on the local and global environment [1]. During this increasing urbanization, balconies of multi-family buildings are replacing courtyards and gardens as a desired private outdoor space [2]. Several recent studies emphasized the idea that access to balconies is one the most desired architectural features, and stressed that this architectural archetype can increase the inhabitants' satisfaction and perception of livability in cities [1,3-7]. Moreover, the current COVID-19 crisis highlighted this collective will of having a private outdoor space in dwellings. During the global confinement, news and opinion articles emerged on public discussion about the growing use and appreciation of balconies, as well as the relevance of including these spaces in home design for the community's welfare.

Even before the recent pandemic crisis, several architecture projects in the last decades had explored the potentialities of the addition of intermediate spaces in dwellings [8,9], not only in order to answer this spatial requirement but also to improve the indoor environmental conditions. It was acknowledged that the balcony spaces added as a prosthesis to a building could have a high capacity of social and spatial transformation, updating the image of buildings, improving the indoor 
comfort conditions, and creating an additional living space. Throughout history, balconies have been recognized as an environmental "buffer space", with the capacity to mediate the outdoor conditions in dwellings [5,10-14]. Acting as an element in-between inside and outside, they transform the indoor environment without resorting to mechanical elements and have been intensively tested in vernacular architecture $[13,15,16]$ and studied as a passive solution to reduce the energy consumption of contemporary buildings [5,11,12,17-20].

The optimization of building envelope design is considered fundamental to improve the indoor environmental quality in dwellings, thus creating healthier, more comfortable, and energy efficient systems [21-23]. The adequate balcony design has been investigated as a step towards sustainable cities and societies. However, despite numerous studies, there is no comprehensive overview of the impacts of balcony design on factors that affect indoor environmental quality (IEQ). For this reason, the main objective of this review is to explore and discuss the impacts of balcony design on the indoor environmental quality and energy efficiency of dwellings.

The present study surveys the previous research on the impacts of balconies on dwellings and classifies the literature according to balcony type, location of the study, and main subject (Section 3). This article provides a detailed description and comprehensive discussion of the features of each balcony design (Section 4) and compares its impacts on the indoor environmental quality factors, investigating the relationships between them (Section 5). Finally, the parameters and the employed methods used to assess the balcony design impacts in the literature are summarized (Section 6).

\section{Material and Methods}

In order to identify relevant studies, a search was conducted in Scopus and Web of Science for articles, books, and conferences in the English language.

The search was conducted in the following fields: article, title, abstract, and keywords. The operator "AND" was used to combinate keywords related to the architectonic characteristics of balconies: "balcony", "glazed balcony", "exterior space", "transitional spaces", "spaces in-between", "buffer spaces", "architectural design", "refurbishment", "apartment buildings" and key terms related to the impacts on the indoor environment of dwellings: "energy", "comfort", "ventilation", "air quality," "luminous comfort", "light", "visual comfort", "acoustic comfort", "indoor environmental quality". The date range included all years available in the database.

The 217 papers returned by the databases were merged in EndNote Library to automatically eliminate the duplicates, resulting in a total of 114 papers. An analysis of the abstracts allowed us to exclude studies outside the scope, such as papers related to balconies of theatres and concert halls, or structural pathologies of balconies. After this selection, 105 papers were analyzed in-depth by reading the full text. This review was conducted in 2019; however, during the process, additional recent articles were considered.

The methodology had three main phases: (1) review of the bibliography according to balcony morphology; (2) classification of the impacts on IEQ factors, building aspects, and the climatic conditions studied; (3) identification of the used assessment methodologies.

\section{An Overview of Balcony Research}

The literature analysis allowed us to define three types of balcony spaces, according to their morphology and their boundary system [24] (Figure 1):

- Open balcony (OB): An open system to the outside-projected balconies, loggias, mashrabiya (balconies protected by carved wood lattice structure, associated with Islamic culture) [25-28], balconies with shading systems (brise-soleil, blinds, curtains) [13,16,29], and green balconies (with vegetation) $[20,30]$;

- Glazed balcony (GB): A closed system with a boundary between the inside and outside space-balconies closed by glass on the outside edge [17,19,31-34], otherwise known as "sunspace" [35-38], or winter gardens [8]; 
- Eliminated balcony (EB): An open system to the indoor space-former balconies that have been eliminated and integrated inside the indoor living area [39].

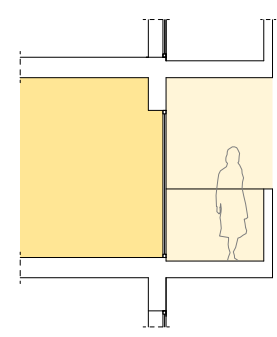

OBI open balcony

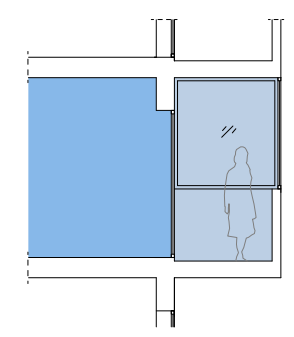

GB I glazed balcony

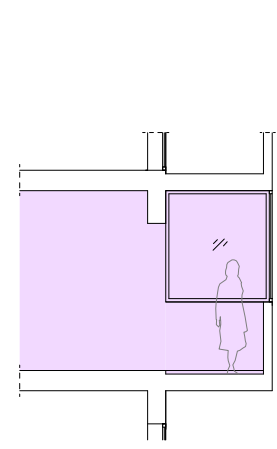

- EB I eliminated balcony

Figure 1. Types of balcony spaces.

The incidences of scientific research about balcony impacts on dwellings are illustrated on the map in Figure 2. It highlights the relation between each balcony type and the specific conditions and constraints of each climatic context. As observed, the studies about open balconies (OB) have a great incidence on high-density cities and were carried out mainly in warm regions such as those with tropical and subtropical climates, and the harsh and arid environmental conditions of the Middle East. The references to open balconies protected by shading systems were mainly related to Muslim countries due to their capacity to comply with the desire of privacy $[15,16,29]$ and the harsh climatic conditions. Recent studies verified that some of these countries have $60-70 \%$ of their energy demands allocated to cooling [40], which can justify the reinterpretation of these traditional shading systems in balconies in order to reduce energy consumption in dwellings.

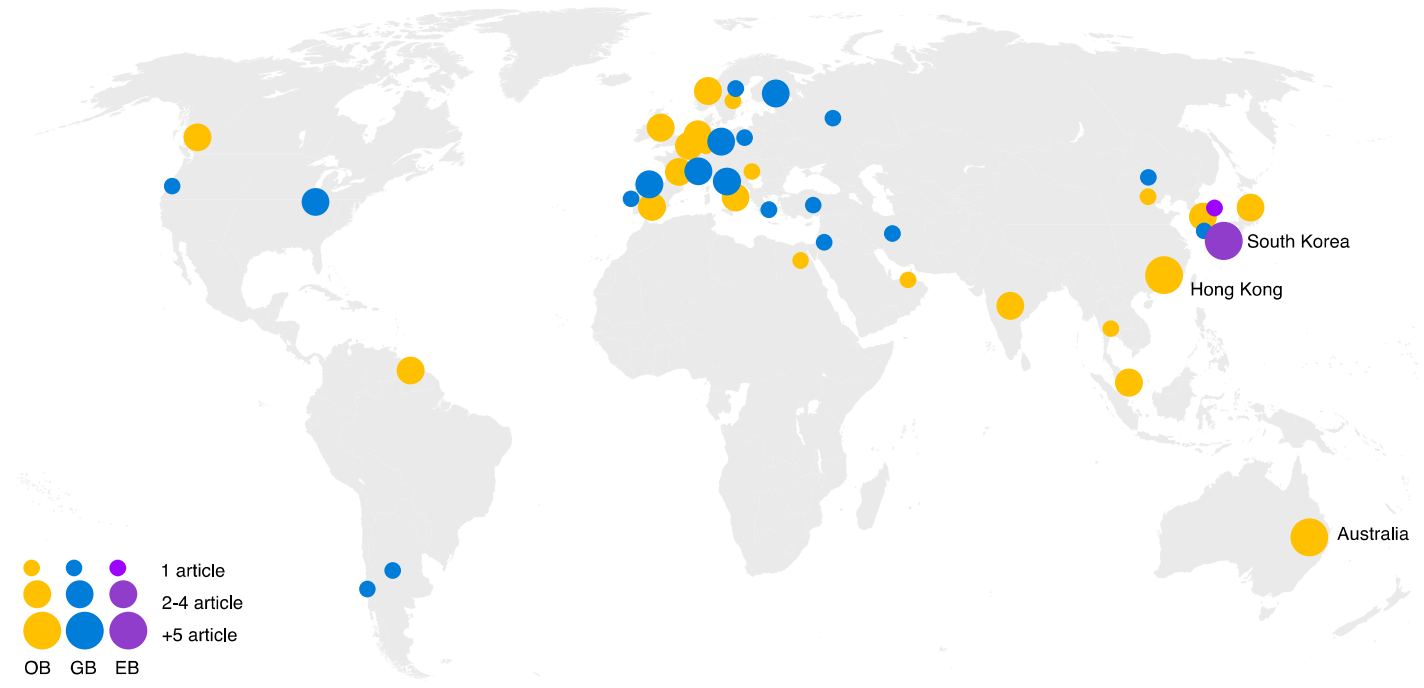

Figure 2. The geographic incidences of papers about the impacts of balcony design.

Articles focused on glazed balconies (GB) have a particular occurrence in cold climates and countries with higher latitudes where the sun angle in wintertime, just before and after the night period, allows the supply of much heat on cold sunny days. However, there are also a number of studies debating the drawbacks of glazed balcony typologies in warm climates and assessing mitigation solutions for the overheating problem. The placement of glass on the edge of balconies was mainly motivated by the desire for an increasing in living space $[29,41]$ and a reduction in traffic noise and air pollution $[4,11]$, despite some studies stating that it should not be a recommended practice from the analysis of energy consumption $[29,42]$. 
In turn, the studies about the eliminated balconies (EB) are focused on the reality of South Korea, where, since 2005, the building code allows balconies to be used as an inside living space and the elimination of balconies became common practice [12,43].

From the analysis of the distribution map of publications, the lack of a comprehensive study about balcony design impacts in mild and Mediterranean climates is clear.

Figure 3 shows that the publications on the passive capacities of balcony spaces are experiencing a growing trend, mainly on low-rise (six stories or less) and high-rise (more than six stories) residential buildings. The literature analysis reveals that the 105 reviewed studies about balconies were published between 1970 and 2020, and cover more topics of research than just glazed or eliminated balconies. Each balcony research topic and its impacts on IEQ is discussed and compared in the following sections.

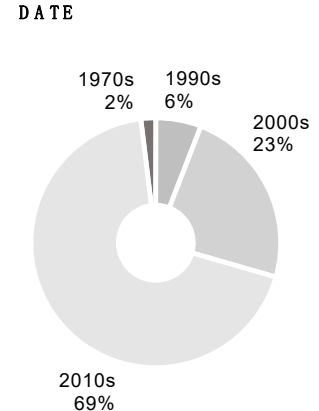

$69 \%$
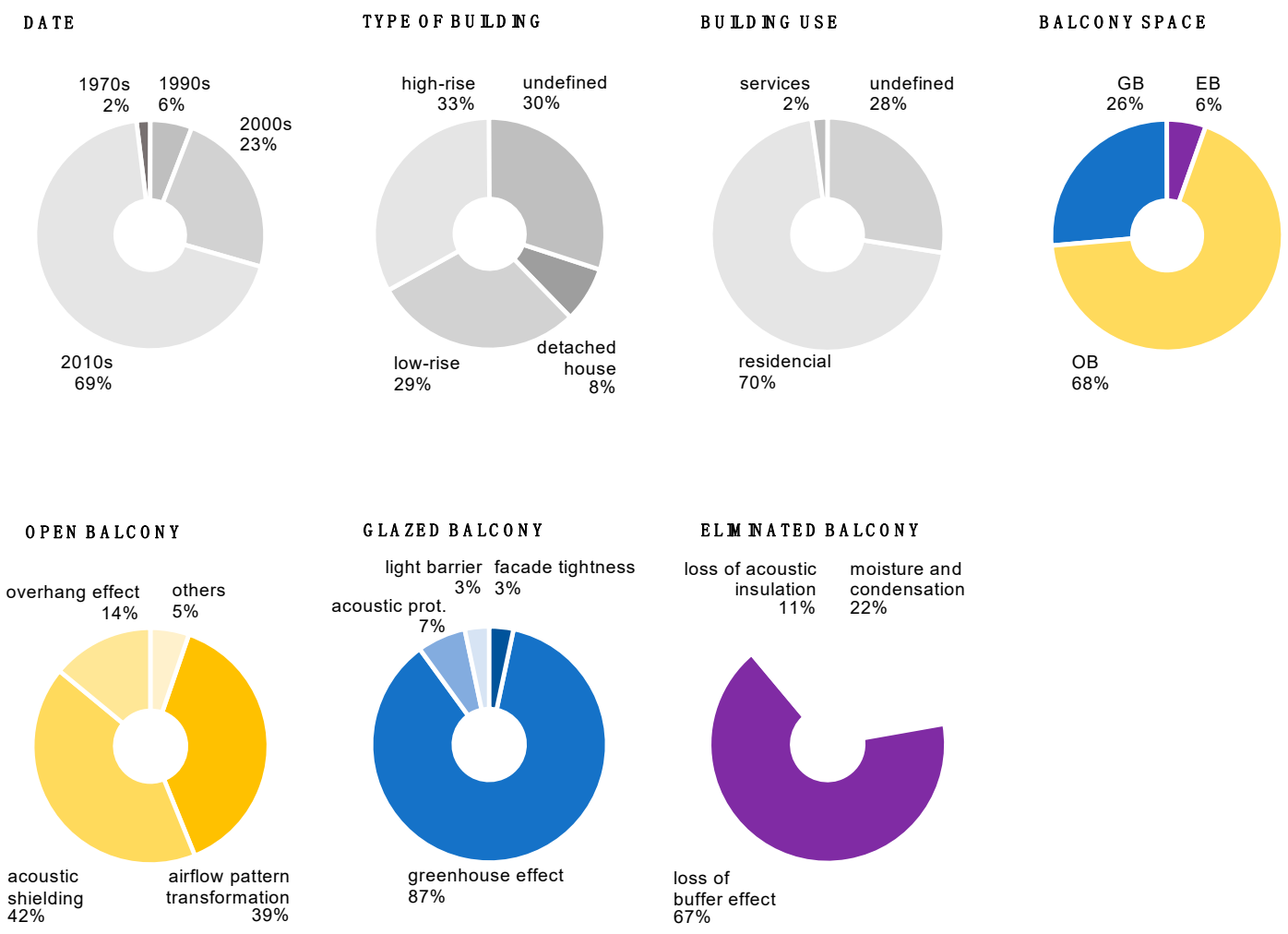

Figure 3. Background of the 105 reviewed studies, within the research topic by balcony type.

\section{Balcony Spaces}

\subsection{Open Balcony}

\subsubsection{Overhang Effect}

The overhang effect is one of the most important features of balconies referred to in the literature. Providing seasonal shading is considered the first line of defense from overheating. The ability of balconies to provide solar shading to the apartment below is referred to as one of the most successful solutions to achieve comfort in summer with low energy consumption [44].

In this regard, Chan and Chow verified that the overhang effect of balconies could reduce the energy load in flats in the subtropical climate of Hong Kong, independently from solar orientation. In this study, focused on cooling energy in the summer season, it was found that the highest savings of annual air-conditioning consumption, up to $12.3 \%$, were achieved by the south/west orientation [45]. Similar studies have been made about the reduction in electric consumption obtained by overhangs. In Shiraz, Iran, with an appropriate overhang shading, a reduction of around $12.7 \%$ in cooling load was obtained during the summer season, with only a marginal increase of $0.6 \%$ in heating demand 
in the winter months [46]. In turn, during the hot summer and in the cold winter zones of China, in Changsha, a reduction of $7.99 \%$ in cooling electric consumption and an increase of $2.83 \%$ in electric heating demand was verified by using an integrative shading of overhangs and fins [47].

Some researchers also indicate that the overhang effect of balconies can block the undesirable penetration of sunlight, protecting the indoor space from ultraviolet radiation [39] and reducing uncomfortable glare $[39,48]$. Besides these benefits on visual comfort, a study carried out by Jamaludin et al. found that a balcony encourages daylighting and contributes to achieving a desired efficient use of electricity in the range of 24 to $34 \mathrm{kWh} / \mathrm{m}^{2} /$ year. In comparison, the average electricity usage varied from 24 to $120 \mathrm{kWh} / \mathrm{m}^{2} /$ year [49].

In this regard, distinct shading systems on balconies have been investigated as passive elements that improve the thermal comfort while providing privacy and enabling inhabitants' interaction [50], like mashrabiya [15,26,42], brise-soleil [16], curtains [29,50], vegetation [20], or adjustable layers of external screening [4].

However, even considering these benefits, the existing balconies in some residential buildings have considerable thermal bridges on balcony slabs, which can be highly harmful to the thermal comfort, indoor air quality, and energy consumption of dwellings [51,52]. In an attempt to minimize this constructive weakness, some studies propose the implementation of balcony thermal breaks [53-55] or the use of low thermal conductivity materials [51] to reduce these thermal bridges.

\subsubsection{Airflow Pattern Transformation}

According to many studies, a balcony can significantly transform the airflow pattern inside and outside of buildings [56-62]. It was proved that the presence of a balcony could improve natural ventilation on the indoor ambient, increase thermal comfort, and consequently reduce the need for mechanical ventilation and, therefore, reduce the energy consumption in buildings [3,59,60,63-65].

This effect is particularly relevant in humid tropical climates where comfort conditions in the buildings can be achieved by attaining sufficient interior air velocity $[57,58]$, and also by increasing the uniformity of indoor air distribution [59,60]. In accordance with this, Bhikhoo et al. carried out research in Bangkok, Thailand that aimed to improve thermal comfort in low-income housing through passive design strategies. It concluded that the presence of a balcony decreases the number of overheating days by $19.94 \%$ due to the significant improvement on indoor ventilation [65].

Additionally, by increasing natural ventilation, several researchers concluded that the presence of a balcony contributes to the reduction of pollutant concentrations on the floor on which balconies are located, improving the air quality [66-68]. Ai et al. found that, in residential buildings, balconies modify the near-wall air flows, changing the characteristics of indoor air re-entry [67]. This is important in the hypothesis of infectious respiratory aerosols because the presence of balconies, except under a normal incident wind, greatly intensifies the transmission of air between dwellings [68].

In this regard, the balcony design parameters that improve natural ventilation have been intensively investigated $[3,63,64,69]$. Omarani et al. analyzed parameters such as balcony type (open and semi-open balconies), balcony depth, ventilation mode, wind angle, and orientation [3]. This study verified that an open balcony achieves a higher indoor air velocity than a semi-enclosed balcony and that the balcony depth decreases the air velocity in both ventilation modes. It was concluded that an appropriate open balcony configuration could be a significant upgrade, specifically in single-sided naturally ventilated dwellings, improving the ventilation performance by up to $80 \%$ [3]. Other investigations found that upper and lower vents in balcony windows could improve natural ventilation [66], and that a wing wall in the balcony could increase the indoor air velocity and airflow rate and improve the airflow distribution in the room [64]. However, recent reviews about the impacts of the geometry of façade openings on natural ventilation suggest that balcony design parameters have not been investigated adequately and recommend further studies $[63,70]$.

Some researchers studied new concepts to control the airflow and create wind protection in high-rise buildings, in which the impact of wind could make cross-ventilation difficult and balconies 
uncomfortable and unsafe for people [4,71]. It was verified that screen and parapet design [71], a semi-open second-skin [72], and vegetation [20] could increase the control of the airflow, reduce wind pressure, and improve comfort conditions on balconies and terraces in high-rise buildings.

\subsubsection{Acoustic Shielding Effect}

Several studies verified that balconies provide an acoustic shielding effect in dwellings. They act as an acoustic protection device against outdoor noise and improve acoustic comfort conditions even with the doors of balconies opened for natural ventilation [73-80].

The optimization of balcony design to increase this acoustic shielding effect has been explored during the last decades. Some studies demonstrate that the different cladding absorbent materials of balcony surfaces on the rear wall and ceiling [79-83], distinct morphologies such as balcony depth $[74,77,79,83]$, height [76], parapets [76,78,79], side walls [76], full balustrades [84], ceiling forms $[74,77,79]$, and ceiling-mounted reflectors $[85,86]$ can greatly reduce the sound pressure level (SPL) of the contiguous room.

Hothersall et al. verified that the maximum noise reduction obtained for a combination of absorbing material on surface treatments was $10 \mathrm{~dB}$ [82]. Regarding the balcony configurations, El Dien and Wolosvyn found that the acoustic shielding effect could be increased with balcony depth and a proper ceiling slope form, so that a noise reduction of $0.5-6 \mathrm{~dB}$ could be achieved [74,77]. Badino et al. highlight the effect of balconies on reducing the leisure noise generated by people talking in the streets and concluded that a geometrically optimized façade cladded with sound absorbing materials achieves the most significant reduction of $10 \mathrm{~dB}$ in mean A-weighted SPL, which corresponds to a mean value of $38 \mathrm{~dB}$ [83].

$\mathrm{Li}$ et al. verified that the increase of height above the balcony floor can decrease the acoustic shield effect. Moreover, the same investigation found that the parapet and side wall performance could increase the acoustic shielding effect when the balcony is parallel to the road, and that the effect becomes less significant when it is perpendicular to the road [76]. Similar studies confirmed that this effect is directly proportional to the floor level, becoming more effective in higher floors where the incident angle is large and without ceiling reflections $[76,77,86]$.

In their research, Naish et al. investigated the relationship between the acoustic shielding effect of balconies and the health costs on a community and verified that balconies have an important merit towards reducing the health costs related to road traffic noise [87].

\subsection{Glazed Balconies}

\subsubsection{Greenhouse Effect}

Many researchers investigated the greenhouse effect of glazed balconies to find out why some worked better than others [17] and if there is a possible real saving on energy performance [19]. In all studies, it was consensual that inside the glazed space the indoor air temperature is higher and the relative humidity is lower than on the outside throughout the year $[17,34,35,38,88,89]$. Confirming this feature of glazed balconies, Fernández-González monitored temperatures during the heating season in Muncie, Indiana, and verified that the monthly average indoor temperature of the attached sunspace was approximately $6.7^{\circ} \mathrm{C}$ higher than the outdoor air temperature [88]. A similar approach carried out by Hilliaho et al. in Tampere, Finland, concluded that over a year, on average, the temperatures of glazed balconies are $5.0^{\circ} \mathrm{C}$ higher than the outdoor air temperature [34].

In this regard, several studies seek ways to maximize the greenhouse effect of the glazed spaces to improve thermal conditions and energy performance. This is especially relevant in cold climates where the sun gains and the reduction of convective heat losses due to stagnant air in the glazed balcony produce a positive effect. It was verified that inclined front glazed surfaces [90], a double-layer of glass $[33,90,91]$, and their use as a preheater for the air supply $[17,41]$ could reduce the heating load requirements. It was also highlighted that the air leakage in glazed balcony structures is the main factor 
affecting the air temperature inside glazed balconies [34], as the exchange of air with the outdoors wastes the energy absorbed and consequently decreases the indoor air temperature [38].

Simultaneously, some recent studies aimed to quantify the energy savings achieved by the greenhouse effects of glazed balconies. Suárez et al. concluded through simulation that in Asturias, northern Spain, a glazed space can provide, on a clear winter day, between $15 \%$ and $32 \%$ of energy savings [92]. Asdrubali et al. found that in the Umbria Region, Italy, the average reduction of energy demand in winter due to the greenhouse effect of a glazed balcony is about $20 \%$ [93]. In turn, the research carried out by Bataineh and Fayez in Amman, Jordan, showed that a sunspace can achieve a reduction of up to $42 \%$ in annual heating and cooling [91]. Babaee et al. had similar results in a study in a cold region of Tabriz, Iran, reducing up to $46 \%$ of the heating load with an optimally designed sunspace [90].

Concerning this feature, it was demonstrated that the amount of energy absorbed by a glazed balcony increases with the intensity of solar radiation [38], and that those oriented to the south have more significant solar gains [32,90]. The highest energy savings were verified in sunny and cold climates such as in the southern European Alps [34], and considering the increased need of heating, the impact on energy savings of glazing is considerably more significant in northern climates [41].

Privitera et al., in their retrospective of the traditional Galician glazed balcony, the Galerías, add that, in La Coruña, the most important benefit of the greenhouse effect is the improvement of the thermal insulation of the stone walls. According to the study, this feature facilitates the moisture evaporation that constitutes one of the main problems in the humid and windy adverse atmospheric conditions of the city [42].

In spite of the positive impact of greenhouse effects on thermal comfort and energy performance verified on cold conditions, several studies have proved that glazed balconies could create severe overheating problems in warm conditions [35,37,91,94-96]. During the summer months, the air temperatures of the continuous living space can exceed comfortable conditions in warm climates, such as in the Middle-East [29,37] and Southern Europe [35,38,97], or even in northern climates [35,98].

Some researches mentioned several passive techniques that could be used during hot summer months to take advantage of the greenhouse effect benefits of glazed balconies while preventing overheating, such as an appropriate solar shading solution and night ventilation [17,35,38,90,91,96,99]. It was suggested that, in warm climate conditions, glazed balconies with south orientation should have shading devices and glazed balconies with west orientation should be avoided [29].

\subsubsection{Facade Tightness}

Hong and Kim, in a study about the air infiltration in high rise residential buildings in Korea, found that the presence of glazed balconies increases the facade tightness, which affects the indoor air quality and the heating and cooling load in buildings [100]. In that research, which measured 45 dwellings using the constant concentration method tracer gas, it was verified that units with exterior windows in the balcony, when closed, have an infiltration rate that is lower by $0.1 \mathrm{~h}^{-1}$ [100].

\subsubsection{Acoustic Insulation}

Some studies mention that glazed balconies have an important role in acoustic protection, increasing sound insulation [11,42]. Kim and Kim evaluated the sound insulation of glazed balconies, proving that windows installed on the edge of balconies could reduce outdoor traffic noise from 27.7 up to $36.2 \mathrm{dBA}$. It was found that windows on both sides of a glazed balcony act as a double window with a large cavity and that the sound insulation performance increases with the width of the balcony [11].

\subsubsection{Light Barrier}

On an investigation focused on the impact of glazed balconies on lighting comfort, Wilson et al. mentioned that a glazed balcony could create a harmful light barrier effect by decreasing the daylighting in the contiguous living spaces. This study revealed that an open balcony with $1.5 \mathrm{~m}$ depth and $2.5 \mathrm{~m}$ 
of height could reduce the daylight by $30-35 \%$, and that value goes up to $60 \%$ when glass is added to the balcony. To solve this problem, the research tested opening a new window in the living space where the daylight had been decreased [19].

\subsection{Eliminated Balconies}

\subsubsection{Loss of Buffer Space Effect}

Some studies mentioned that the elimination of an existing balcony, and its assimilation into the indoor living area, causes the loss of an environmental buffer space and the consequent loss of the referred advantages of an intermediate space in-between the indoor and outdoor conditions [12,43].

Due to the balcony elimination, a significant increase of heat loss through windows was proved to exist during the winter season. The excessive penetration of direct sunlight in summer days caused thermal discomfort and increased energy consumption. Kim et al. measured the air temperature for three days in December, in Seoul, and verified that the average indoor air temperature of a room with a balcony was $1{ }^{\circ} \mathrm{C}$ higher than one without a balcony [12]. In a similar study, also in Seoul, Song and Choi obtained an identical result, a difference of $0.8^{\circ} \mathrm{C}$ in the winter season [43]. That research verified that the heating and cooling loads of the living space in flats where balcony spaces were removed were respectively $39 \%$ and $22 \%$ higher than when the balcony space was maintained [43].

Moreover, some researches proved that the elimination of balconies could cause visual discomfort in the adjacent room, such as uncomfortable glare due to the excessive penetration of direct sunlight $[39,101]$. In recent research, several solutions have been tested to mitigate these negative effects, such as the application of shading devices, the use of glazing with low transmittance [39], or the implementation of a double skin façade [102].

\subsubsection{Moisture and Condensation}

The moisture and condensation effect are mentioned in some studies as a consequence of balcony elimination and a result of the poor insulation of the balcony space $[12,103]$. In a questionnaire survey, carried out by Choi et al., answered by 2755 parents in Seoul, $61.6 \%$ of homeowners with a changed balcony complained about mold and indoor dampness problems, such as floor moisture and condensation [103]. In that study, rhinitis symptoms were more frequently reported among children living in dwellings where balconies were eliminated, with this change increasing the risk of health problems among the residents.

To combat the problem of condensation on window surfaces in winter due to the removal of balcony spaces in Korean dwellings, Kim et al. tested a double window system with improved thermal performance and ventilation slits [12]. The results demonstrate that an open outer window bottom vent and an inner window top ventilation slit could be an efficient solution for these widespread problems.

\subsubsection{Loss of Acoustic Insulation}

The elimination of the balcony space due to its integration into the indoor space may cause acoustic problems. A study in South Korea examined the sound insolation performance in apartments whose balcony was removed with the aim of determining whether it met the building regulations against outside noise [104]. However, in the literature, a consistent evaluation of this impact was not found.

\section{Summary of Balcony Impacts}

The previous analysis of balcony space demonstrates that the three balcony types (open balcony, glazed balcony, and eliminated balcony) have relevant impacts on the indoor environment and on the energy consumption of dwellings.

Table 1 summarizes the properties of each balcony type and its consequent impacts on four factors that influence the IEQ. By analyzing these impacts, it is clear that the presence of an open balcony on 
dwellings could improve all four IEQ factors. However, the presence of a glazed balcony, depending on the context and the climatic conditions, can have positive impacts on some factors, but can also have negative impacts on others, thus compromising the global IEQ. At the same time, the elimination of the balcony space may have the benefit of increasing the indoor space. Still, there are no advantages found in the literature for this specific intervention to the indoor environment.

Some balcony features influence more than one IEQ factor simultaneously, creating connections between them, as illustrated in Figure 4. The connections between each feature and their impacts are represented in the central circle, and the four factors and sub-factors of IEQ are located at the circle circumference. It is clear, by analyzing the circle, that the features related to outside noise reduction are those that produce more connections between IEQ factors. Those features related to outside noise reduction encourage the opening of windows for natural ventilation, impacting simultaneously the acoustic comfort, thermal comfort, and indoor air quality (IAQ).

Previous research confirmed that the benefits of natural ventilation can conflict with the need to reduce the ingress of external noise in urban areas $[105,106]$. Cooling energy consumption in buildings can be $20 \%$ less in quiet environments compared to noisy locations [105]. Therefore, this balcony feature is particularly relevant in the high density cities of subtropical climates, such as Brisbane [3,4], Hong Kong [5], and Kuala Lumpur [6] where the traffic causes acoustic discomfort and poor air quality. In this context, the capacity of balconies to reduce noise encourages more frequent window openings, therefore increasing natural ventilation and improving thermal comfort and indoor air quality, while contributing to the reduction of energy consumption.

The trend of populational migration to urban areas remains, as does the increasing occurrence of heat waves or prolonged summers. These trends are modifying the needs of high-rise residential buildings in cold climates [107]. Therefore, in these climates, the aforementioned benefits of balconies also become very relevant.

The relation between the IEQ factors has a strong influence on the energy performance of dwellings [21,22]. However, in the studies about the optimization of balcony spaces to improve energy consumption, outlined in Figure 5, the indoor thermal conditions were the primary factor under consideration.

As observed, under certain optimized conditions, an open balcony can reduce the energy consumption for cooling in the summer by up to $12.3 \%$ [45]. In turn, a glazed balcony can have an increased impact, and reduce the energy consumption for heating by up to $46 \%$, in cold climates [90]. The impact may not always reach this figure in buildings with a high heating energy demand, but the overall contribution is potentially positive in cold climates. However, if the design is not adequate to the context, a glazed balcony could create severe overheating problems and an up to $65 \%$ increase in the energy consumption for cooling in the summer [33]. This confirms that poor indoor environmental conditions can lead to excessive use of energy, therefore the elimination or incorporation of a balcony can increase the energy consumption both in summer and in winter [43].

These results demonstrate the importance of adapting the balcony design to each particular context and climatic condition. Balcony design impacts should be considered simultaneously for all of the IEQ factors. Therefore, further studies are required to fill the gap identified in this review. 
Table 1. Summary of the impacts of balcony spaces on the indoor environment quality (IEQ) of dwellings. Key: $+=$ positive impacts, $-=$ negative impacts.

\begin{tabular}{|c|c|c|c|c|}
\hline IEQ Factors & & Open Balcony Impacts & Glazed Balcony Impacts & Eliminated Balcony Impacts \\
\hline \multirow[t]{2}{*}{ Thermal comfort } & + & $\begin{array}{c}\text { overhang effect-provides solar shading } \\
\text { airflow pattern transformation-increases the } \\
\text { natural ventilation } \\
\text { acoustic shielding effect-reduces background } \\
\text { noise with doors open, enabling an increase of } \\
\text { natural ventilation }\end{array}$ & $\begin{array}{l}\text { greenhouse effect-increase in solar gains } \\
\text { with a positive effect in heating } \\
\text { season conditions }\end{array}$ & - \\
\hline & - & - & $\begin{array}{l}\text { greenhouse effect-can lead to excessive } \\
\text { heat gains and create overheating problems } \\
\text { in cooling season conditions }\end{array}$ & $\begin{array}{c}\text { loss of buffer space effect-increases the } \\
\text { heat loss and excessive penetration of } \\
\text { direct sunlight }\end{array}$ \\
\hline \multirow[t]{2}{*}{ Air quality } & + & $\begin{array}{l}\text { airflow pattern transformation-increases the } \\
\text { air flow rate } \\
\text { acoustic shielding effect-reduces background } \\
\text { noise with doors open, enabling an increase of } \\
\text { natural ventilation }\end{array}$ & $\begin{array}{l}\text { greenhouse effect-improves the thermal } \\
\text { insulation and facilitate the evaporation } \\
\text { of moisture }\end{array}$ & - \\
\hline & - & & $\begin{array}{l}\text { increase facade tightness-decreases the } \\
\text { air infiltration rate and the } \\
\text { natural ventilation }\end{array}$ & $\begin{array}{c}\text { condensation and moisture-the typical } \\
\text { poor insulation of the balcony space can } \\
\text { cause mold and indoor dampness problems } \\
\text { loss of acoustic insulation-decreases doors } \\
\text { openings, provoking a reduction of } \\
\text { natural ventilation }\end{array}$ \\
\hline \multirow[t]{2}{*}{ Visual comfort } & + & $\begin{array}{c}\text { overhang effect-blocks the undesirable } \\
\text { penetration of sunlight, reducing } \\
\text { uncomfortable glare }\end{array}$ & - & - \\
\hline & - & & $\begin{array}{l}\text { light barrier-decreases the daylight in the } \\
\text { contiguous living spaces }\end{array}$ & $\begin{array}{l}\text { loss of buffer space effect-provokes } \\
\text { excessive penetration of direct sunlight }\end{array}$ \\
\hline \multirow[t]{2}{*}{ Acoustic comfort } & + & $\begin{array}{c}\text { acoustic shielding effect-acts as a protection } \\
\text { device against outdoor noise }\end{array}$ & $\begin{array}{c}\text { acoustic protection-acts as an acoustic } \\
\text { barrier against outdoor noise }\end{array}$ & - \\
\hline & - & - & - & $\begin{array}{c}\text { loss of acoustic insulation-causes indoor } \\
\text { acoustic problems }\end{array}$ \\
\hline
\end{tabular}




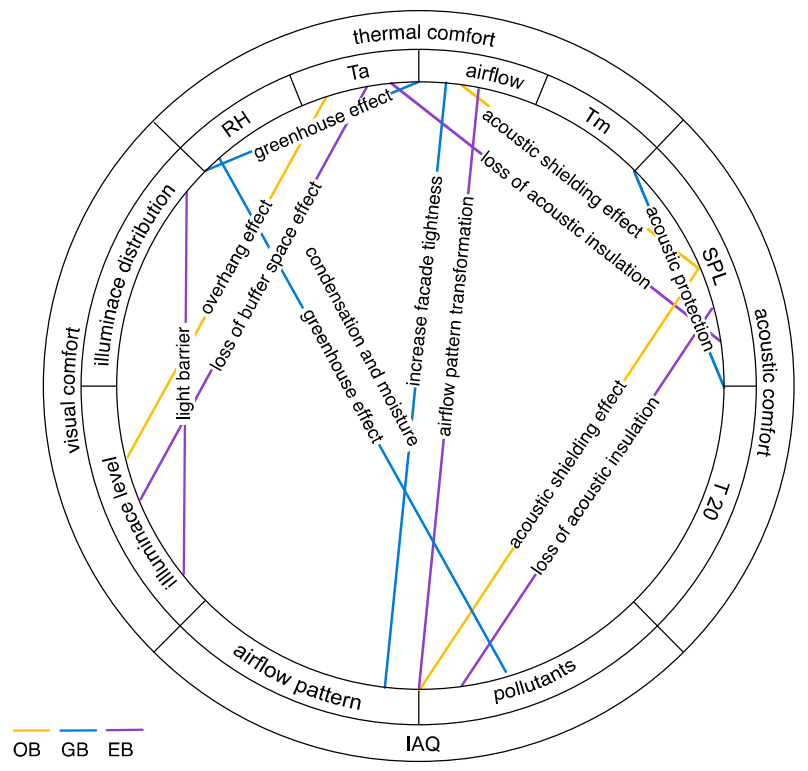

Figure 4. Correlation between balcony space features and their impacts on IEQ factors. Key: $\mathrm{RH}=\mathrm{Relative}$ Humidity, $\mathrm{Ta}=$ Air temperature, $\mathrm{Tr}=$ Mean radiant temperature, SPL $=$ Sound Pressure Level, $\mathrm{T} 20=$ Reverberation time, IAQ $=$ Indoor Air Quality.

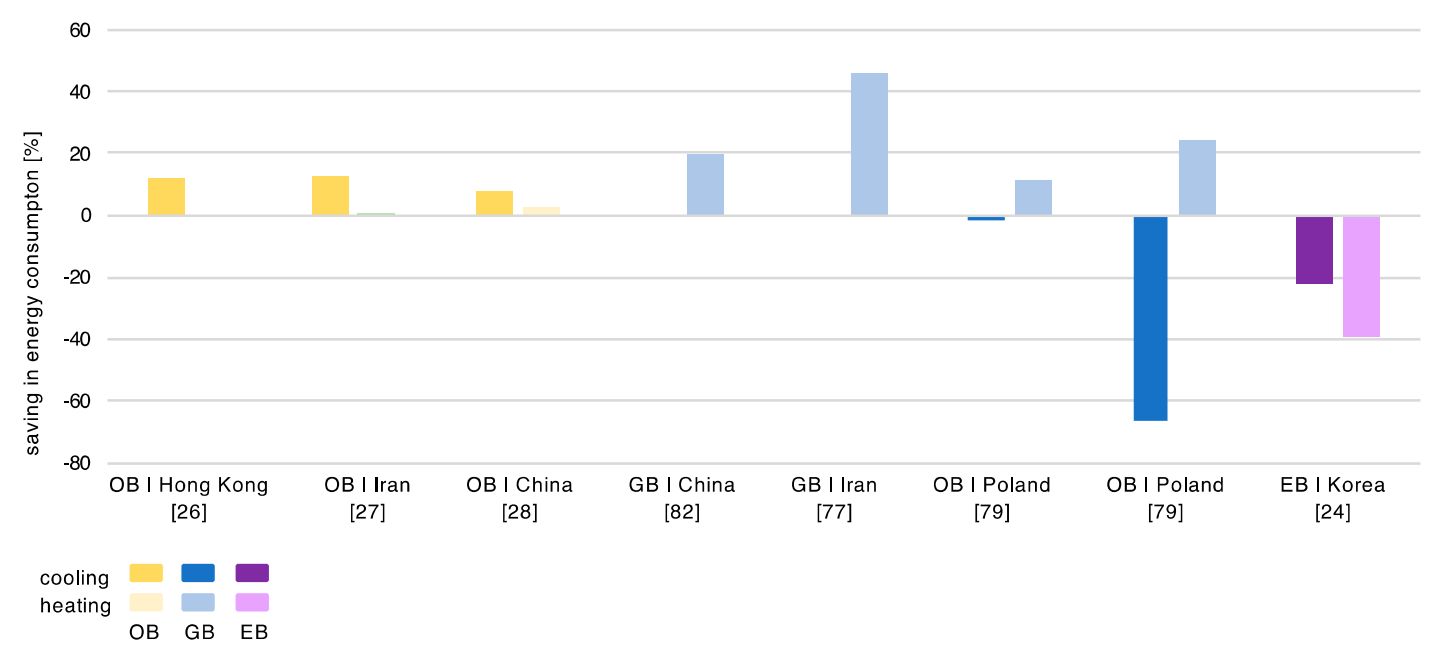

Figure 5. Balcony space impacts on energy consumption identified in the literature.

\section{Assessment Methods of Balcony Impacts}

An accurate assessment of balcony design impacts on indoor environment quality factors is essential to outline more suitable solutions, as determined in the previous section. In order to identify the most suitable methods to evaluate the balcony impact on IEQ factors, Table 2 lists the analyzed parameters, applied methods, types of balcony studied, and the location and season for each research case.

The results show that thermal comfort is the factor with the greatest number of analyzed parameters, for which authors employed a more extensive range of in-situ monitoring methodologies and simulations. Based on the occupants' perceptions of indoor environmental conditions in dwellings, some studies concluded that thermal comfort is the most influential factor for overall occupants' satisfaction $[6,23,108,109]$, which may justify this significant amount of studies.

Concerning in-situ campaigns related to thermal impact, the indoor air temperature and relative humidity of the balcony space, contiguous space, and the outside air are usually monitored at the same time. These approaches were used to evaluate the impact of open balconies, glazed balconies, and eliminated balconies in distinct climatic contexts for both heating and cooling seasons. In addition, 
some of these studies evaluated the airflow pattern. However, some studies in subtropical climates focused solely on the impacts of open balconies by evaluating the airflow pattern and velocity through in-situ monitoring campaigns or computational fluid dynamics (CFD) simulation.

Still on the topic of the thermal impact of balconies, a relevant number of identical approaches evaluated the energy performance of distinct balcony configurations, orientations, and protection systems in a wide range of climatic contexts using simulation programs.

Table 2. Summary of the impacts of balcony spaces on the indoor environment quality of dwellings.

\begin{tabular}{|c|c|c|c|c|c|c|}
\hline IEQ Factors & Parameters & & Assessment Methods & Balcony Type & Location, Season & Ref. \\
\hline \multirow{11}{*}{$\begin{array}{l}\text { Thermal } \\
\text { comfort }\end{array}$} & $\begin{array}{c}\text { Air } \\
\text { temperature }\end{array}$ & Ta & In-situ monitoring & $\begin{array}{c}\text { OB } \\
\text { OB/GB } \\
\text { OB/GB } \\
\text { GB } \\
\text { GB/EB } \\
\text { GB }\end{array}$ & $\begin{array}{l}\text { Malaysaia, cooling s. } \\
\text { Libano, cooling s. } \\
\text { Tampere, both s. } \\
\text { Isparta, heating s. } \\
\text { Seoul, heating s. } \\
\text { Portugal, both s. }\end{array}$ & $\begin{array}{c}{[6,110]} \\
{[29]} \\
{[34]} \\
{[37]} \\
{[43]} \\
{[96]}\end{array}$ \\
\hline & $\begin{array}{c}\text { Mean } \\
\text { radiant } \\
\text { temperature }\end{array}$ & $\operatorname{Tr}$ & In-situ monitoring & $\begin{array}{c}\text { GB/EB } \\
\text { GB } \\
\text { GB }\end{array}$ & $\begin{array}{l}\text { Seoul, heating s. } \\
\text { Muncie, heating s. } \\
\text { Portugal, both s. }\end{array}$ & $\begin{array}{l}{[43]} \\
{[88]} \\
{[96]}\end{array}$ \\
\hline & $\begin{array}{l}\text { Relative } \\
\text { Humidity }\end{array}$ & $\mathrm{RH}$ & In-situ monitoring & $\begin{array}{c}\text { OB } \\
\text { GB } \\
\text { GB } \\
\text { GB/EB } \\
\text { GB } \\
\text { GB }\end{array}$ & $\begin{array}{l}\text { Malaysaia, cooling s. } \\
\text { Isparta, heating s. } \\
\text { Isparta, heating s. } \\
\text { Seoul, heating s. } \\
\text { Muncie, heating s. } \\
\text { Portugal, both s. }\end{array}$ & $\begin{array}{c}{[6,110]} \\
{[34]} \\
{[37]} \\
{[43]} \\
{[88]} \\
{[96]}\end{array}$ \\
\hline & \multirow[t]{2}{*}{$\begin{array}{c}\text { Airflow } \\
\text { pattern and } \\
\text { velocity }\end{array}$} & & In-situ monitoring & $\begin{array}{c}\mathrm{OB} \\
\mathrm{GB} / \mathrm{EB} \\
\mathrm{GB}\end{array}$ & $\begin{array}{l}\text { Brisbane, cooling s. } \\
\text { Seoul, heating s. } \\
\text { Portugal, both s. }\end{array}$ & $\begin{array}{c}{[3]} \\
{[43]} \\
{[96]}\end{array}$ \\
\hline & & & Simulation: CFD & $\begin{array}{l}\text { OB } \\
\text { OB }\end{array}$ & $\begin{array}{c}\text { Brisbane, cooling s. } \\
-\end{array}$ & $\begin{array}{c}{[3]} \\
{[59]}\end{array}$ \\
\hline & \multirow{6}{*}{$\begin{array}{c}\text { Energy } \\
\text { consumption }\end{array}$} & & $\begin{array}{l}\text { Simulation: } \\
\text { EnergyPlus }\end{array}$ & $\begin{array}{l}\text { OB } \\
\text { OB } \\
\text { GB } \\
\text { GB }\end{array}$ & $\begin{array}{l}\text { Hong Kong, both s. } \\
\text { Barcelona, both s. } \\
\text { Tabriz, heating s. } \\
\text { Poland, cooling s. }\end{array}$ & $\begin{array}{l}{[45]} \\
{[50]} \\
{[90]} \\
{[98]}\end{array}$ \\
\hline & & & EDSL TAS & $\mathrm{OB} / \mathrm{GB}$ & Libano, cooling s. & [29] \\
\hline & & & IES VE & OB & Bangkok, cooling s. & {$[65]$} \\
\hline & & & TRNSYS & $\begin{array}{c}\text { GB/EB } \\
\text { GB }\end{array}$ & $\begin{array}{l}\text { Seoul, both s } \\
\text { Italy, heating s. }\end{array}$ & $\begin{array}{l}{[43]} \\
{[93]}\end{array}$ \\
\hline & & & Clim2000 s & GB & Lyon, - & [94] \\
\hline & & & IDA-ICE 4.6.1 & GB & Tampere, both s. & {$[41]$} \\
\hline \multirow[t]{2}{*}{ IAQ } & \multirow[t]{2}{*}{$\begin{array}{c}\text { Airflow } \\
\text { pattern and } \\
\text { velocity }\end{array}$} & & $\begin{array}{l}\text { In-situ monitoring: } \\
\text { tracer gas technique }\end{array}$ & $\mathrm{OB} / \mathrm{GB}$ & Korea, both s. & [100] \\
\hline & & & Simulation: CFD & $\begin{array}{l}\text { OB } \\
\text { OB }\end{array}$ & $\begin{array}{c}\text { Malaysia, cooling s. } \\
-\end{array}$ & $\begin{array}{c}{[64]} \\
{[66-68,111]}\end{array}$ \\
\hline \multirow{4}{*}{$\begin{array}{l}\text { Visual } \\
\text { comfort }\end{array}$} & \multirow{3}{*}{$\begin{array}{c}\text { Illuminace } \\
\text { level }\end{array}$} & \multirow{3}{*}{$\mathrm{E}$} & In-situ monitoring & OB & Malaysia, cooling s. & {$[6]$} \\
\hline & & & Simulation: Radiance & EB & Korea, - & [39] \\
\hline & & & Daysim into Energy & - & Abu Dabi, - & [25] \\
\hline & $\begin{array}{l}\text { Illuminace } \\
\text { distribution }\end{array}$ & $\mathrm{Ed}$ & In-situ monitoring & - & Korea, - & {$[101]$} \\
\hline
\end{tabular}


Table 2. Cont.

\begin{tabular}{|c|c|c|c|c|c|c|}
\hline IEQ Factors & Parameters & & Assessment Methods & Balcony Type & Location, Season & Ref. \\
\hline \multirow{7}{*}{$\begin{array}{l}\text { Acoustic } \\
\text { comfort }\end{array}$} & \multirow{6}{*}{$\begin{array}{l}\text { Sound } \\
\text { pressure } \\
\text { levels }\end{array}$} & \multirow{6}{*}{ SPL } & In-situ monitoring & $\begin{array}{l}\text { OB } \\
\text { GB } \\
\text { OB } \\
\text { OB } \\
\text { OB }\end{array}$ & $\begin{array}{c}\text { Malaysia, cooling s. } \\
\text { Korea, - } \\
\text { Korea, - } \\
\text { Turin., - } \\
\text { - }\end{array}$ & $\begin{array}{c}6] \\
{[11]} \\
{[78]} \\
{[83]} \\
{[86,112]}\end{array}$ \\
\hline & & & $\begin{array}{l}\text { Measurements: by } \\
\text { scale models }\end{array}$ & OB & Korea, - & [78] \\
\hline & & & Simulation: COMSOL & OB & - & [80] \\
\hline & & & $\begin{array}{c}\text { Pyramid Tracing } \\
\text { model }\end{array}$ & OB & & {$[74,77]$} \\
\hline & & & RAY- NOISE & OB & Korea, - & {$[78]$} \\
\hline & & & Pachyderm & OB & Turin., - & [83] \\
\hline & $\begin{array}{l}\text { Reverberation } \\
\text { time }\end{array}$ & $\mathrm{T} 20$ & In-situ monitoring & OB & Korea, - & {$[78]$} \\
\hline
\end{tabular}

\section{Conclusions}

Regarding the impact on indoor air quality, a large number of studies used monitoring and CFD simulation programs to evaluate the impact of balcony design on the indoor airflow patterns and air velocity. No studies with other indoor air quality assessment methodologies related to balconies were found, such as the monitoring of the concentration of pollutants such as $\mathrm{CO}_{2}$, total of volatile compounds (TVOCs), and fine particulate matter, smaller than $2.5 \mu \mathrm{m}\left(\mathrm{PM}_{2.5}\right)$. This could be an opportunity for research in further studies.

The studies that investigate the impacts of balconies on visual comfort were carried out by in-situ monitoring and simulation programs, measuring mainly illuminance levels. However, a study that assessed the effect of occupant's interactions with shading systems on indoor daylight monitored the illuminance distribution [101], which could be a future research opportunity regarding balcony design optimization.

Finally, with respect to the assessment of the impacts on acoustic comfort, balcony shapes and materials have been systematically tested by field campaigns and numeral simulation programs. The studies using in-situ measurements show some similarities: The sound pressure levels (SPL) were measured in two rooms, one with and another without a balcony. The sound source was an omnidirectional speaker in the proximity [78] or alternatively the presence of a constant noise source near the building, such as a railway [86] or a highway. The wide range of these studies aimed to optimize the open balconies' capacity to reduce the outdoor noise; other balcony typologies, their precise location, or the climatic conditions were not considered.

In spite of the wide range of distinct strategies to assess balcony impacts, an evaluation approach of the morphological aspects of the three balcony typologies in the context of IEQ factors is yet to be determined. For that reason, further research on more comprehensive assessment methodologies is recommended, taking into account the vast number of parameters influenced by balcony design.

This comprehensive review of balcony impacts led to the identification of three balcony spaces according to their morphology and their boundary system: open balcony (OB), glazed balcony (GB), and eliminated balcony (EB). From the reviewed studies, it becomes evident that the three balcony spaces have relevant impacts on the four factors that contribute to indoor environmental quality (thermal comfort, air quality, visual comfort, and acoustic comfort).

The analysis of the geographic incidence of the scientific research, in the context of the discussion of each balcony impact on IEQ, demonstrated the suitability of each balcony space for distinct climatic conditions and latitudes.

The research studies focused on the design optimization of open balconies (OB) constitute the majority of the reviewed papers $(68 \%)$, occurring more significantly in tropical and subtropical 
high-density cities and warm climates. The literature clarified that the existence of an open balcony on dwellings contributes towards improving all four IEQ factors and the overall indoor environment.

Concerning the glazed balconies (GB), the large majority of the studies were carried out in cold climatic conditions where there was an interest in maximizing the greenhouse effect in order to improve thermal conditions and reduce the energy demand on heating. However, the reviewed studies demonstrate that glazed balconies could compromise the global IEQ by creating overheating problems, decreasing the air infiltration rate, and reducing daylight incidence within the contiguous living space. Several studies were also focused on glazed balconies in warm climatic conditions, proposing passive techniques to prevent overheating, such as appropriate solar shading solutions and the opening of windows during the night for ventilation.

In turn, the studies about eliminated balconies (EB) were carried out based on the comparison between the advantages of open and glazed balconies, aimed at reducing the drawbacks of losing the buffer space effect of the former balcony (67\%). Some of these studies tested mitigation solutions, such as the application of shading devices, the use of glazing with low transmittance, the implementation of a double skin, or the addition of a double window system or ventilation slits.

In the literature reviewed, there was a clear lack of a comprehensive study about the impacts of the three different balcony spaces when in mild and Mediterranean climates. The literature also demonstrates the limitations of existing knowledge concerning the balance and the connection between the impacts of balcony features on IEQ factors and the energy consumption of buildings.

Finally, certain limitations of this review must be addressed. Although there were a large number of reviewed articles, it was not possible to go deeper into the morphologic analysis because not enough information was found concerning the dimensions and architectonic design options of balconies. Another limitation was solely considering studies published in English. As this is a subject with particular relevance to Asiatic high-density cities, it would be worthwhile for future researches to review documents published in other languages.

This subject is of particular relevance for dense and compact cities with warm summers. Nevertheless, considering the fact that growing urbanization and climate changes are modifying the comfort needs of high-rise residential buildings in mild and cold climates, this review recommends more holistic studies on balcony design as a way to achieve a more sustainable development.

Author Contributions: Conceptualization, C.R., N.M.M.R., and I.F.-C.; methodology, C.R.; formal analysis, C.R.; investigation, C.R.; resources, C.R.; writing-original draft preparation, C.R.; writing-review and editing, C.R., N.M.M.R., and I.F.-C.; visualization, C.R.; supervision, N.M.M.R. and I.F.-C.; project administration, N.M.M.R. and I.F.-C.; funding acquisition, N.M.M.R. and I.F.-C. All authors have read and agreed to the published version of the manuscript.

Funding: This research received no external funding.

Acknowledgments: The first author would like to acknowledge the support of FCT—Fundação para a Ciência e a Tecnologia, the funding of the Doctoral Grant PD/BD/135164/2017, through the Doctoral Programme EcoCoRe. This work was financially supported by Base Funding-UIDB/04708/2020 of the CONSTRUCT-Instituto de I\&D em Estruturas e Construções-funded by national funds through the FCT/MCTES (PIDDAC).

Conflicts of Interest: The authors declare no conflict of interest.

\section{References}

1. Kotulla, T.; Denstadli, J.M.; Oust, A.; Beusker, E. What does it take to make the compact city liveable for wider groups? Identifying key neighbourhood and dwelling features. Sustainability 2019, 11, 3480. [CrossRef]

2. Kerr, S.M.; Klocker, N.; Gibson, C. From backyards to balconies: Cultural norms and parents' experiences of home in higher-density housing. Hous. Stud. 2020. [CrossRef]

3. Omrani, S.; Garcia-Hansen, V.; Capra, B.R.; Drogemuller, R. On the effect of provision of balconies on natural ventilation and thermal comfort in high-rise residential buildings. Build. Environ. 2017, 123, 504-516. [CrossRef]

4. Kennedy, R.; Buys, L.; Miller, E. Residents' experiences of privacy and comfort in multi-storey apartment dwellings in subtropical Brisbane. Sustainability 2015, 7, 7741-7761. [CrossRef] 
5. Chau, K.W.; Wong, S.K.; Yiu, C.Y. The value of the provision of a balcony in apartments in Hong Kong. Prop. Manag. 2004, 22, 250-264. [CrossRef]

6. Dahlan, N.D.; Jones, P.J.; Alexander, D.K.; Salleh, E.; Alias, J. Evidence base prioritisation of indoor comfort perceptions in Malaysian typical multi-storey hostels. Build. Environ. 2009, 44, 2158-2165. [CrossRef]

7. Wågø, S.; Hauge, B.; Støa, E. Between indoor and outdoor: Norwegian perceptions of well-being in energy-efficient housing. J. Arch. Plan. Res. 2016, 33, 329-346.

8. Drout, F.; Anne, L.; Vassal, J.-P. Plus: Large-Scale Housing Developments. An Exceptional Case; Editorial Gustavo Gili: Barcelona, Spain, 2004; ISBN 978-84-252-2163-7.

9. Rivkin, A. Espaciar: El horizonte post-mediático de la obra de Lacaton \& Vassal. In Horizonte Post-Mediático: Lacaton y Vassal, 1993-2015; El Croquis Editorial: Madrid, Spain, 2015; pp. 33-47, ISBN 978-84-88386-84-7.

10. Chun, C.; Kwok, A.; Tamura, A. Thermal comfort in transitional spaces-Basic concepts: Literature review and trial measurement. Build. Environ. 2004, 39, 1187-1192. [CrossRef]

11. Kim, M.-J.; Kim, H.-G. Field measurements of façade sound insulation in residential buildings with balcony windows. Build. Environ. 2007, 42, 1026-1035. [CrossRef]

12. Kim, J.; Kim, T.; Leigh, S.B. Double window system with ventilation slits to prevent window surface condensation in residential buildings. Energy Build. 2011, 43, 3120-3130. [CrossRef]

13. Requena-Ruiz, I. Bioclimatism in the Architecture of Le Corbusier: The millowners association building. Inf. La Constr. 2012, 64, 549-562. [CrossRef]

14. Raji, B.; Tenpierik, M.J.; van den Dobbelsteen, A. Early-stage design considerations for the energy-efficiency of high-rise office buildings. Sustainability 2017, 9, 623. [CrossRef]

15. Fathy, H. Natural Energy and Vernacular Architecture; University of Chicago Press: Chicago, IL, USA, 1986; ISBN 0-226-23917-9.

16. Pastor, C.E. The integration of light: LeCorbusier. Ega Rev. Expr. Graf. Arquit. 2018, 23, 62-75. [CrossRef]

17. Wall, M. Climate and Energy Use in Glazed Spaces. Ph.D. Thesis, Lund University, Lund, Sweden, 1996.

18. Hilliaho, K.; Kovalainen, V.; Huuhka, S.; Lahdensivu, J. Glazed spaces: A simplified calculation method for the evaluation of energy savings and interior temperatures. Energy Build. 2016, 125, 27-44. [CrossRef]

19. Wilson, M.P.; Jorgensen, O.B.; Johannesen, G. Daylighting, energy and glazed balconies: A study of a refurbishment project in Engelsby, near Flensberg, Germany. Light. Res. Technol. 2000, 32, 127-132. [CrossRef]

20. Raji, B.; Tenpierik, M.J.; van den Dobbelsteen, A. The impact of greening systems on building energy performance: A literature review. Renew. Sustain. Energy Rev. 2015, 45, 610-623. [CrossRef]

21. Heinzerling, D.; Schiavon, S.; Webster, T.; Arens, E. Indoor environmental quality assessment models: A literature review and a proposed weighting and classification scheme. Build. Environ. 2013, 70, 210-222. [CrossRef]

22. Montazami, A.; Gaterell, M.; Nicol, F. A comprehensive review of environmental design in UK schools: History, conflicts and solutions. Renew. Sustain. Energy Rev. 2015, 46, 249-264. [CrossRef]

23. Sakhare, V.V.; Ralegaonkar, R.V. Indoor environmental quality: Review of parameters and assessment models. Archit. Sci. Rev. 2014, 57, 147-154. [CrossRef]

24. Srinivasan, R.; Moe, K. The Hierarchy of Energy in Architecture: Emergy Analysis; Routledge: London, UK, 2015; ISBN 978-1-138-80352-7.

25. Giovannini, L.; Lo Verso, V.R.M.; Karamata, B.; Andersen, M. Lighting and energy performance of an adaptive shading and daylighting system for arid climates. In Proceedings of the 6th International Building Physics Conference (IBPC), Torino, Italy, 14-17 June 2015; pp. 370-375.

26. Almerbati, N.; Headley, D.; Ford, P.; Taki, A. From manual to hybrid, parametric Mashrabiya: Digital workflow for the re-envisioning and conservation of eastern architectural screens and the engagement of digital tectonics. Int. J. Architecton. Spat. Environ. Des. 2016, 10, 29-39. [CrossRef]

27. Kansara, T. Transitional zone design in the desert environment of Abu Dhabi: Vernacular vs. modern. Sustain. Cities Soc. 2016, 23, 59-67. [CrossRef]

28. Mossé, A. Gossamer timescapes: A design-led investigation into electro-active and light responsive textiles for the home. Smart Mater. Struct 2018, 27. [CrossRef]

29. Saleh, P.H. Thermal performance of glazed balconies within heavy weight/thermal mass buildings in Beirut, Lebanon's hot climate. Energy Build. 2015, 108, 291-303. [CrossRef] 
30. Besir, A.B.; Cuce, E. Green roofs and facades: A comprehensive review. Renew. Sustain. Energy Rev. 2018, 82, 915-939. [CrossRef]

31. Voss, K. Solar energy in building renovation—results and experience of international demonstration buildings. Energy Build. 2000, 32, 291-302. [CrossRef]

32. Fernandes, J.; Pimenta, C.; Mateus, R.; Silva, S.M.; Braganca, L. Contribution of Portuguese Vernacular Building Strategies to Indoor Thermal Comfort and Occupants' Perception. Buildings 2015, 5, 1242-1264. [CrossRef]

33. Grudzinska, M. Glazed balconies as passive greenhouse systems-Potential of their use in Poland. Build. Serv. Eng. Res. Technol. 2016, 37, 555-572. [CrossRef]

34. Hilliaho, K.; Kolio, A.; Pakkala, T.; Landensivu, J.; Vinha, J. Effects of added glazing on Balcony indoor temperatures: Field measurements. Energy Build. 2016, 128, 458-472. [CrossRef]

35. Mihalakakou, G. On the use of sunspace for space heating/cooling in Europe. Renew. Energy 2002, 26, 415-429. [CrossRef]

36. Mottard, J.-M.; Fissore, A. Thermal simulation of an attached sunspace and its experimental validation. Sol. Energy 2007, 81, 305-315. [CrossRef]

37. Dikmen, N. Performance analysis of the external wall thermal insulation systems applied in residences. J. Therm. Sci. Technol. 2011, 31, 67-76.

38. Oliveti, G.; Arcuri, N.; De Simone, M.; Bruno, R. Solar heat gains and operative temperature in attached sunspaces. Renew. Energy 2012, 39, 241-249. [CrossRef]

39. Kim, G.; Kim, J.T. Healthy-daylighting design for the living environment in apartments in Korea. Build. Environ. 2010, 45, 287-294. [CrossRef]

40. Touma, A.A.; Ouahrani, D. The selection of brise soleil shading optical properties for energy conservation and glare removal: A case study in Qatar. J. Build. Eng. 2018, 20, 510-519. [CrossRef]

41. Hilliaho, K.; Mäkitalo, E.; Lahdensivu, J. Energy saving potential of glazed space: Sensitivity analysis. Energy Build. 2015, 99, 87-97. [CrossRef]

42. Privitera, P.; Diodato, M.; García Sáez, S. Solar radiation influence on pre-modern openings features: La Coruña and Valletta. In Vernacular Architecture: Towards a Sustainable Future; CRC Press/Balkema: Leiden, The Netherlands, 2014; pp. 637-642, ISBN 9781315736907.

43. Song, D.; Choi, Y.-J. Effect of building regulation on energy consumption in residential buildings in Korea. Renew. Sustain. Energy Rev. 2012, 16, 1074-1081. [CrossRef]

44. Hastings, S.R. Breaking the "heating barrier": Learning from the first houses without conventional heating. Energy Build. 2004, 36, 373-380. [CrossRef]

45. Chan, A.L.S.; Chow, T.T. Investigation on energy performance and energy payback period of application of balcony for residential apartment in Hong Kong. Energy Build. 2010, 42, 2400-2405. [CrossRef]

46. Raeissi, S.; Taheri, M. Optimum overhang dimensions for energy saving. Build. Environ. 1998, 33, $293-302$. [CrossRef]

47. Yu, J.; Yang, C.; Tian, L. Low-energy envelope design of residential building in hot summer and cold winter zone in China. Energy Build. 2008, 40, 1536-1546. [CrossRef]

48. Xue, P.; Mak, C.M.; Cheung, H.D.; Chao, J. Post-occupancy evaluation of sunshades and balconies' effects on luminous comfort through a questionnaire survey. Build. Serv. Eng. Res. Technol. 2016, 37, 51-65. [CrossRef]

49. Jamaludin, A.A.; Mahmood, N.Z.; Ilham, Z. Performance of electricity usage at residential college buildings in the University of Malaya campus. Energy Sustain. Dev. 2017, 40, 85-102. [CrossRef]

50. Foged, I.W. Thermal responsive performances of a Spanish balcony-based vernacular envelope. Buildings 2019, 9, 80. [CrossRef]

51. Alhawari, A.; Mukhopadhyaya, P. Thermal bridges in building envelopes-An overview of impacts and solutions. Int. Rev. Appl. Sci. Eng. 2018, 9, 31-40. [CrossRef]

52. Ge, H.; Baba, F. Effect of dynamic modeling of thermal bridges on the energy performance of residential buildings with high thermal mass for cold climates. Sustain. Cities Soc. 2017, 34, 250-263. [CrossRef]

53. Ge, H.; McClung, V.R.; Zhang, S. Impact of balcony thermal bridges on the overall thermal performance of multi-unit residential buildings: A case study. Energy Build. 2013, 60, 163-173. [CrossRef]

54. Baba, F.; Ge, H. Dynamic effect of balcony thermal bridges on the energy performance of a high-rise residential building in Canada. Energy Build. 2016, 116, 78-88. [CrossRef] 
55. Wang, Y.; Fukuda, H. The influence of insulation styles on the building energy consumption and indoor thermal comfort of multi-family residences. Sustainability 2019, 11, 266. [CrossRef]

56. Chand, I.; Bhargava, P.K.; Krishak, N.L.V. Effect of balconies on ventilation inducing aeromotive force on low-rise buildings. Build. Environ. 1998, 33, 385-396. [CrossRef]

57. Prianto, E.; Depecker, P. Characteristic of airflow as the effect of balcony, opening design and internal division on indoor velocity: A case study of traditional dwelling in urban living quarter in tropical humid region. Energy Build. 2002, 34, 401-409. [CrossRef]

58. Prianto, E.; Depecker, P. Optimization of architectural design elements in tropical humid region with thermal comfort approach. Energy Build. 2003, 35, 273-280. [CrossRef]

59. Ai, Z.T.; Mak, C.M.; Niu, J.L.; Li, Z.R. Effect of balconies on thermal comfort in wind-induced, naturally ventilated low-rise buildings. Build. Serv. Eng. Res. Technol. 2011, 32, 277-292. [CrossRef]

60. Ai, Z.T.; Mak, C.M.; Niu, J.L.; Li, Z.R. The assessment of the performance of balconies using computational fluid dynamics. Build. Serv. Eng. Res. Technol. 2011, 32, 229-243. [CrossRef]

61. Mohamed, M.F.; Prasad, D.; King, S.; Hirota, K. The impact of balconies on wind induced ventilation of single-sided naturally ventilated multi-storey apartment. In Proceedings of the PLEA2009. 26th Conference on Passive and Low Energy Architecture, Quebec City, QC, Canada, 22-24 June 2009.

62. Kahsay, M.T.; Bitsuamlak, G.T.; Tariku, F. CFD simulation of external CHTC on a high-rise building with and without façade appurtenances. Build. Environ. 2019, 165. [CrossRef]

63. Izadyar, N.; Miller, W.; Rismanchi, B.; Garcia-Hansen, V. Impacts of façade openings' geometry on natural ventilation and occupants' perception: A review. Build. Environ. 2020, 170. [CrossRef]

64. Mozaffari Ghadikolaei, F.; Ossen, D.R.; Mohamed, M.F. Effects of wing wall at the balcony on the natural ventilation performance in medium-rise residential buildings. J. Build. Eng. 2020, 31. [CrossRef]

65. Bhikhoo, N.; Hashemi, A.; Cruickshank, H. Improving thermal comfort of low-income housing in Thailand through passive design strategies. Sustainability 2017, 9, 1440. [CrossRef]

66. Cui, D.J.; Mak, C.M.; Niu, J.L. Effect of balconies and upper-lower vents on ventilation and indoor air quality in a wind-induced, naturally ventilated building. Build. Serv. Eng. Res. Technol. 2014, 35, 393-407. [CrossRef]

67. Ai, Z.T.; Mak, C.M.; Niu, J.L. Numerical investigation of wind-induced airflow and interunit dispersion characteristics in multistory residential buildings. Indoor Air 2013, 23, 417-429. [CrossRef]

68. Ai, Z.T.; Mak, C.M. A study of interunit dispersion around multistory buildings with single-sided ventilation under different wind directions. Atmos. Environ. 2014, 88, 1-13. [CrossRef]

69. Jin, R.; Hang, J.; Liu, S.; Wei, J.; Liu, Y.; Xie, J.; Sandberg, M. Numerical investigation of wind-driven natural ventilation performance in a multi-storey hospital by coupling indoor and outdoor airflow. Indoor Built Environ. 2016, 25, 1226-1247. [CrossRef]

70. Sha, H.; Qi, D. A Review of High-Rise Ventilation for Energy Efficiency and Safety. Sustain. Cities Soc. 2020, 54. [CrossRef]

71. Irwin, P.A. Wind engineering challenges of the new generation of super-tall buildings. J. Wind Eng. Ind. Aerodyn. 2009, 97, 328-334. [CrossRef]

72. Montazeri, H.; Blocken, B.; Janssen, W.D.; van Hooff, T. CFD evaluation of new second-skin facade concept for wind comfort on building balconies: Case study for the Park Tower in Antwerp. Build. Environ. 2013, 68, 179-192. [CrossRef]

73. Kropp, W.; Berillon, J. A theoretical model to investigate the acoustic performance of building facades in the low and middle frequency range. Acustica 1998, 84, 681-688.

74. El Dien, H.H.; Woloszyn, P. Balcony form-An approach to reduce sound pressure level into the building façade. Wit Trans. Built Environ. 2003, 69, 349-358.

75. El-Dien, H.H. Acoustic performance of high rise building façades due to its balconies form. Acta Acust. 2003, 89. [CrossRef]

76. Li, K.M.; Lui, W.K.; Lau, K.K.; Chan, K.S. A simple formula for evaluating the acoustic effect of balconies in protecting dwellings against road traffic noise. Appl. Acoust. 2003, 64, 633-653. [CrossRef]

77. El Dien, H.H.; Woloszyn, P. Prediction of the sound field into high-rise building facades due to its balcony ceiling form. Appl. Acoust. 2004, 65, 431-440. [CrossRef]

78. Lee, P.J.; Kim, Y.H.; Jeon, J.Y.; Song, K.D. Effects of apartment building façade and balcony design on the reduction of exterior noise. Build. Envrion. 2007, 42, 3517-3528. [CrossRef] 
79. Naish, D.A.; Tan, A.C.C.; Demirbilek, F.N. Simulating the effect of acoustic treatment types for residential balconies with road traffic noise. Appl. Acoust. 2014, 79, 131-140. [CrossRef]

80. Wang, X.; Mao, D.; Yu, W.; Jiang, Z. Acoustic performance of balconies having inhomogeneous ceiling surfaces on a roadside building facade. Build. Environ. 2015, 93, 1-8. [CrossRef]

81. May, D.N. Freeway noise and high-rise balconies. J. Acoust. Soc. Am. 1979, 65, 699-704. [CrossRef]

82. Hothersall, D.C.; Horoshenkov, K.V.; Mercy, S.E. Numerical modelling of the sound field near a tall building with balconies near a road. J. Sound Vib. 1996, 198, 507-515. [CrossRef]

83. Badino, E.; Manca, R.; Shtrepi, L.; Calleri, C.; Astolfi, A. Effect of façade shape and acoustic cladding on reduction of leisure noise levels in a street canyon. Build. Environ. 2019, 157, 242-256. [CrossRef]

84. Barbaro, S.; Caracausi, R.; Rapin, J.M. Control of acoustical quality of indoor spaces: Thorough analysis of the influence of façade typologies. Build. Acoust. 2001, 8, 161-177. [CrossRef]

85. Ishizuka, T.; Fujiwara, K. Traffic noise reduction at balconies on a high-rise building facade. J. Acoust. Soc. Am. 2012, 131, 2110-2117. [CrossRef]

86. Ishizuka, T.; Fujiwara, K. Full-scale tests of reflective noise-reducing devices for balconies on high-rise buildings. J. Acoust. Soc. Am. 2013, 134, EL185-EL190. [CrossRef]

87. Naish, D.A.; Tan, A.C.C.; Demirbilek, F.N. Estimating health related costs and savings from balcony acoustic design for road traffic noise. Appl. Acoust. 2012, 73, 497-507. [CrossRef]

88. Fernández-González, A. Analysis of the thermal performance and comfort conditions produced by five different passive solar heating strategies in the United States midwest. Sol. Energy 2007, 81, 581-593. [CrossRef]

89. Hilliaho, K.; Lahdensivu, J.; Vinha, J. Glazed space thermal simulation with IDA-ICE 4.61 software-Suitability analysis with case study. Energy Build. 2015, 89, 132-141. [CrossRef]

90. Babaee, F.; Fayaz, R.; Sarshar, M. The optimum design of sunspaces in apartment blocks in cold climate. Archit. Sci. Rev. 2016, 59, 239-253. [CrossRef]

91. Bataineh, K.M.; Fayez, N. Analysis of thermal performance of building attached sunspace. Energy Build. 2011, 43, 1863-1868. [CrossRef]

92. Suárez, M.J.; Gutiérrez, A.J.; Pistono, J.; Blanco, E. CFD analysis of heat collection in a glazed gallery. Energy Build. 2011, 43, 108-116. [CrossRef]

93. Asdrubali, F.; Cotana, F.; Messineo, A. On the evaluation of solar greenhouse efficiency in building simulation during the heating period. Energies 2012, 5, 1864-1880. [CrossRef]

94. Roux, J.J.; Teodosiu, C.; Covalet, D.; Chareille, R. Validation of a glazed space simulation model using full-scale experimental data. Energy Build. 2004, 36, 557-565. [CrossRef]

95. Abdullah, A.H.; Meng, Q.; Zhao, L.; Wang, F. Field study on indoor thermal environment in an atrium in tropical climates. Build. Environ. 2009, 44, 431-436. [CrossRef]

96. Fernandes, J.; Malheiro, R.; De Fátima Castro, M.; Gervásio, H.; Silva, S.M.; Mateus, R. Thermal performance and comfort condition analysis in a vernacular building with a glazed balcony. Energies 2020, 13, 624 . [CrossRef]

97. Aelenei, D.; De Azevedo Leal, H.; Aelenei, L. The use of attached-sunspaces in retrofitting design: The case of residential buildings in Portugal. Energy Procedia 2014, 48, 1436-1441. [CrossRef]

98. Nowak-Dzieszko, K.; Rojewska-Warchał, M. Influence of the Balcony Glazing Construction on Thermal Comfort of Apartments in Retrofitted Large Panel Buildings. Procedia Eng. 2015, 108, 481-487. [CrossRef]

99. Berezin, D.V. Exterior Space Retrofitting Planning with Possible Effect on Building Thermal Characteristics. In Proceedings of the IOP Conference Series Materials Science and Engineering, Irkutsk, Russia, 21-22 September 2017.

100. Hong, G.; Kim, B.S. Field measurements of infiltration rate in high rise residential buildings using the constant concentration method. Build. Environ. 2016, 97, 48-54. [CrossRef]

101. Shin, H.Y.; Kim, G.; Kim, J.T. Effect of Occupants' Behaviour of Daylight Controls on Residential Visual Environment. Indoor Built Environ. 2013, 22, 191-202. [CrossRef]

102. Yoon, Y.B.; Seo, B.; Koh, B.B.; Cho, S. Performance analysis of a double-skin façade system installed at different floor levels of high-rise apartment building. J. Build. Eng. 2019, 26. [CrossRef]

103. Choi, J.; Chun, C.; Sun, Y.; Choi, Y.; Kwon, S.; Bornehag, C.G.; Sundell, J. Associations between building characteristics and children's allergic symptoms-A cross-sectional study on child's health and home in Seoul, South Korea. Build. Environ. 2014, 75, 176-181. [CrossRef] 
104. Park, H.K.; Song, G.G.; Kim, Y.; Kim, S.W. Airborne sound insulation against outdoor noise in balcony remodeled apartment. In Proceedings of the 17th International Congress on Sound and Vibration, Cairo, Egypt, 18-22 July 2010; pp. 775-779.

105. Barclay, M.; Kang, J.; Sharples, S. Combining noise mapping and ventilation performance for non-domestic buildings in an urban area. Build. Environ. 2012, 52, 68-76. [CrossRef]

106. Cui, S.; Perret-Gentil, M.; Gourdon, E.; Barthelmé, A.-F.; Mankibi, M.E.; Wurtz, E.; Stabat, P.; Marchio, D. A global modelling approach of natural ventilation with acoustic and daylighting constraints. Int. J. Vent. 2016, 15, 233-252. [CrossRef]

107. Baba, F.; Ge, H. Effect of climate change on the energy performance and thermal comfort of high-rise residential buildings in cold climates. In Proceedings of the CESBP, Praha, Czech, 2-5 September 2019.

108. Lai, J.H.K.; Yik, F.W.H. Perception of importance and performance of the indoor environmental quality of high-rise residential buildings. Build. Environ. 2009, 44, 352-360. [CrossRef]

109. Altomonte, S.; Rutherford, P.; Wilson, R. Indoor Environmental Quality: Lighting and Acoustics. Encycl. Sustain. Technol. 2017, 221-229. [CrossRef]

110. Dahlan, N.D.; Jones, P.J.; Alexander, D.K.; Salleh, E.; Dixon, D. Field measurement and subjects' votes assessment on thermal comfort in high-rise hostels in Malaysia. Indoor Built Environ. 2008, 17, 334-345. [CrossRef]

111. Zheng, X.; Montazeri, H.; Blocken, B. CFD simulations of wind flow and mean surface pressure for buildings with balconies: Comparison of RANS and LES. Build. Environ. 2020, 173. [CrossRef]

112. Cabrera, D.; Yadav, M.; Holmes, J.; Fong, O.; Caldwell, H. Incidental acoustic retroreflection from building façades: Three instances in Berkeley, Sydney and Hong Kong. Build. Environ. 2020, 172. [CrossRef]

(C) 2020 by the authors. Licensee MDPI, Basel, Switzerland. This article is an open access article distributed under the terms and conditions of the Creative Commons Attribution (CC BY) license (http://creativecommons.org/licenses/by/4.0/). 